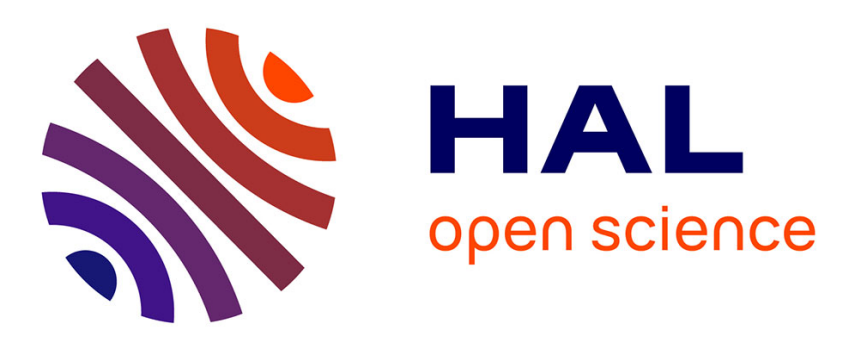

\title{
Mechanism of austenitic transformation in the martensitic stainless steel of type $\mathrm{PH}$ 15-5
}

H. Habibi Bajguirani

\section{To cite this version:}

H. Habibi Bajguirani. Mechanism of austenitic transformation in the martensitic stainless steel of type PH 15-5. Journal de Physique IV Proceedings, 1994, 04 (C3), pp.C3-123-C3-126. 10.1051/jp4:1994317 . jpa-00252514

\section{HAL Id: jpa-00252514 https://hal.science/jpa-00252514}

Submitted on 1 Jan 1994

HAL is a multi-disciplinary open access archive for the deposit and dissemination of scientific research documents, whether they are published or not. The documents may come from teaching and research institutions in France or abroad, or from public or private research centers.
L'archive ouverte pluridisciplinaire HAL, est destinée au dépôt et à la diffusion de documents scientifiques de niveau recherche, publiés ou non, émanant des établissements d'enseignement et de recherche français ou étrangers, des laboratoires publics ou privés. 


\title{
Mechanism of austenitic transformation in the martensitic stainless steel of type PH 15-5
}

\author{
H.R. HABIBI BAJGUIRANI
}

ISMA, Université de Paris-Sud, Laboratoire de Métallurgie Structurale, UA 1107 du CNRS, Bât. 413, 91405 Orsay, France

\begin{abstract}
By dilatometric analysis and TEM experiments, the martensite $(M) \rightarrow$ austenite $(\gamma)$ transformation and the formation of the precipitates in PH 15-5 alloy were studied between 20 and $1050^{\circ} \mathrm{C}$, using heating rate $\left(R_{h}\right)$, and cooling rate $\left(R_{c}\right)=300^{\circ} \mathrm{C} . h^{-1}$. For this heating rate the $\mathrm{M} \rightarrow \gamma$ transformation develops in two steps. Detailed analysis of the diffusion processes controlling the two stages of the austenite transformation, was carried out, using cumulated thermal cycles between 600 and $1050^{\circ} \mathrm{C}$.
\end{abstract}

\section{INTRODUCTION}

Martensitic stainless alloys are widely used in the aeronautic and nuclear industries. These alloys contain a small amount of carbon ( $0.05 \%$ in weight ) in order to avoid the formation of carbides or carbonitrides.

Some authors [1], [2], [3] have studied the austenite transformation of martensitic steels of type maraging ( $\mathrm{Fe} \mathrm{Ni} \mathrm{Co} \mathrm{Mo} \mathrm{and} \mathrm{Fe} \mathrm{Mn} \mathrm{Co} \mathrm{Mo}$ ) according to the heating rate. In these types of alloys they pointed out that the austenite transformation proceeds in two steps if the heating rate is kept moderate $\left(300^{\circ} \mathrm{C} \cdot \mathrm{h}^{-1}\right)$.

In this work, we studied such phenomena in a martensitic steel of type PH 15-5 with the following chemical composition (in weight \%) : Balance Fe- $14.8 \mathrm{Cr}-4.87 \mathrm{Ni}-3.10 \mathrm{Cu}-0.75 \mathrm{Mn}-0.30 \mathrm{Nb}-$ $0.28 \mathrm{Si}$ and $0.041 \mathrm{C}$.

Furthermore, in this study we were able to determine the temperature ranges at which the formation of hardening precipitates (based on $\mathrm{Cu}$ ) took place in the matrix.

\section{RESULTS AND DISCUSSION}

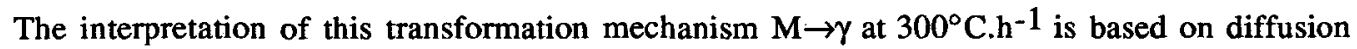
processes.

Following this argumentation, we are going to present the mechanism of austenitic transformation in the case described below, i.e. the nominal chemical composition Co and an initial uniform martensitic structure at room temperature (Figure 1):

-during the heating process $\left(300^{\circ} \mathrm{C} . \mathrm{h}^{-1}\right)$ at a temperature below $442^{\circ} \mathrm{C}$, Figure 2 , the formation of clusters $(\mathrm{Cu})$ leads to the new composition $\mathrm{C}_{\mathrm{Mp}}$ of a new martensitic phase, impoverished in elements like $\mathrm{Cu}$ and $\mathrm{Ni}$ (called $\mathrm{Mp}$ ).

-between $442^{\circ} \mathrm{C}$ and $530^{\circ} \mathrm{C}$ a part of the formed clusters which are not already transformed into stable embryos leading to the formation of precipitates enriched in copper [4], dissolves in the martensitic matrix, leading to an enriched martensitic $\mathrm{M}_{\mathrm{r}}$ of composition $\mathrm{C}_{\mathrm{Mr}}>\mathrm{Co}$ [3]. 


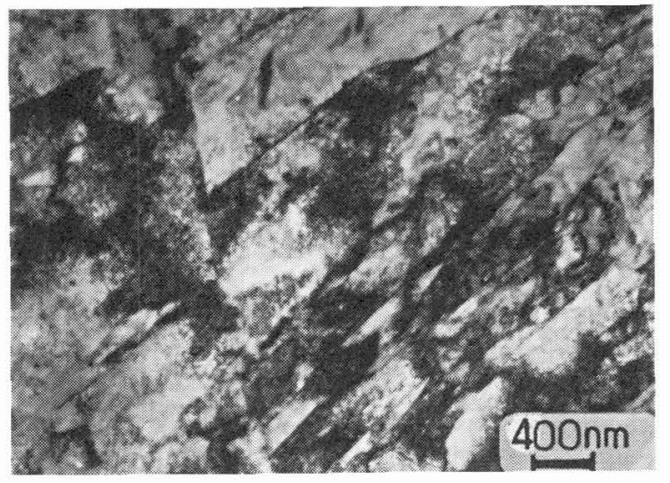

Figure 1 : Bright field micrograph showing initial uniform martensitic structure at room temperature.

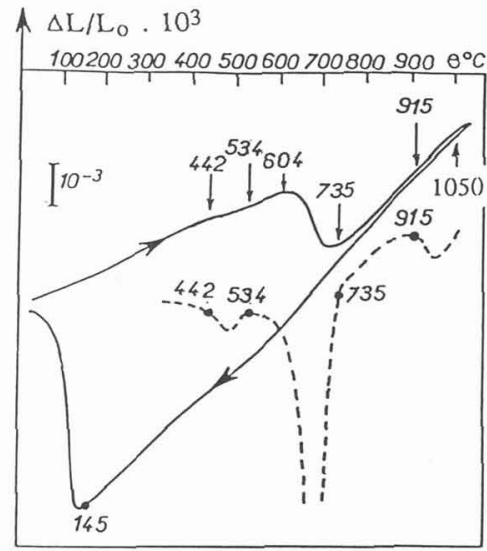

Figure 2:- Dilatometric curves of PH 15-5 alloy $\left(R_{h}=R_{c}=300^{\circ} \mathrm{C} \cdot h^{-1}\right)$. ---- Derivative curve.

The other particles are transformed into stable embryos, the embryos of the precipitates. After a certain growth time the latter show a crystalline structure of the f.c.c. structure [5], called (A), Figure 3a.

a

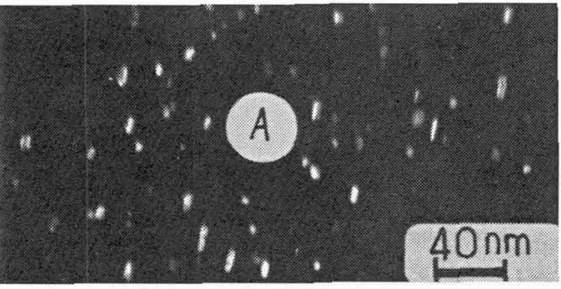

C

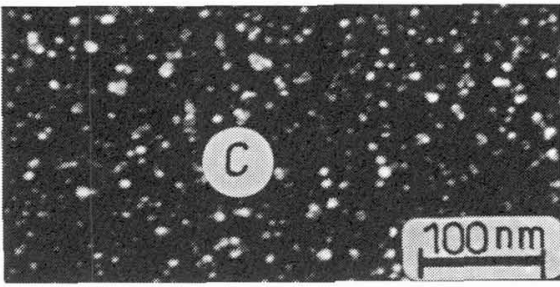

$\mathbf{A} \rightarrow \mathbf{B}$

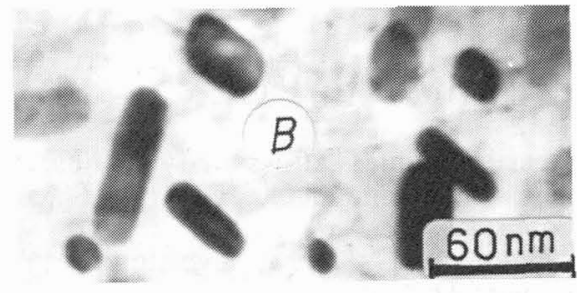

$C \rightarrow D$

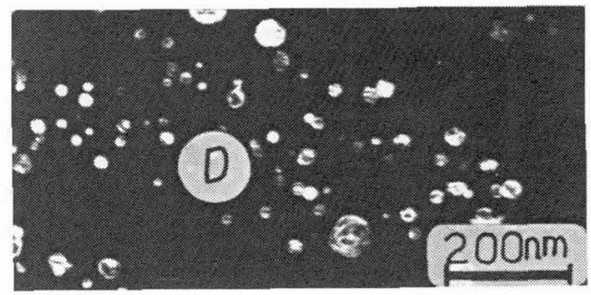

Figure 3 : (a) Alloy aged at $500^{\circ} \mathrm{C}$ for $64 \mathrm{~h}$; dark field micrograph showing A type precipitates. The precipitates exhibit a double lobe strain field contrast or a striated contrast.

(b) Alloy aged at $650^{\circ} \mathrm{C}$ for $64 \mathrm{~h}$; brihgt field micrograph showing $\mathrm{B}$ type precipitates as rods.

(c) Alloy aged at $700^{\circ} \mathrm{C}$ for $16 \mathrm{~h}$; dark field micrograph recorded on C type precipitates.

(d) Alloy aged at $750^{\circ} \mathrm{C}$ for $64 \mathrm{~h}$; dark field micrograph recorded on B type precipitates.

At the beginning of the first step of the austenitic transformation, the following processes take place successively:

- formation of an enriched austenite $\gamma_{\mathrm{mr}}$ with the elements of the alloy, in particular the $\mathrm{Cu}$ and $\mathrm{Ni}$ during the reaction; $M_{r} \rightarrow M_{r p}+\gamma_{r r}$ [6], accompanied by a decrease of these elements in the neighbouring martensitic zones(Mp).

The diffusion processes are involved in the first step of the austenitic transformation and could be detected as follows :

The obtained Ms values ( during the final cooling process) vary as a function of the beginning of the transformation in the heating step; the formed austenite is completely stable at room temperature because no $\mathrm{Ms}$ point is observed for $\theta>20^{\circ} \mathrm{C}$ on the dilatometric curves. 
When we increased the maximal temperature reached $\theta_{\text {Max }}$ (in the heating process), Figure $4 a, b$, the corresponding temperatures of the Ms values in the cooling process increased progressively in the same way, Figure $4 \mathrm{c}$.
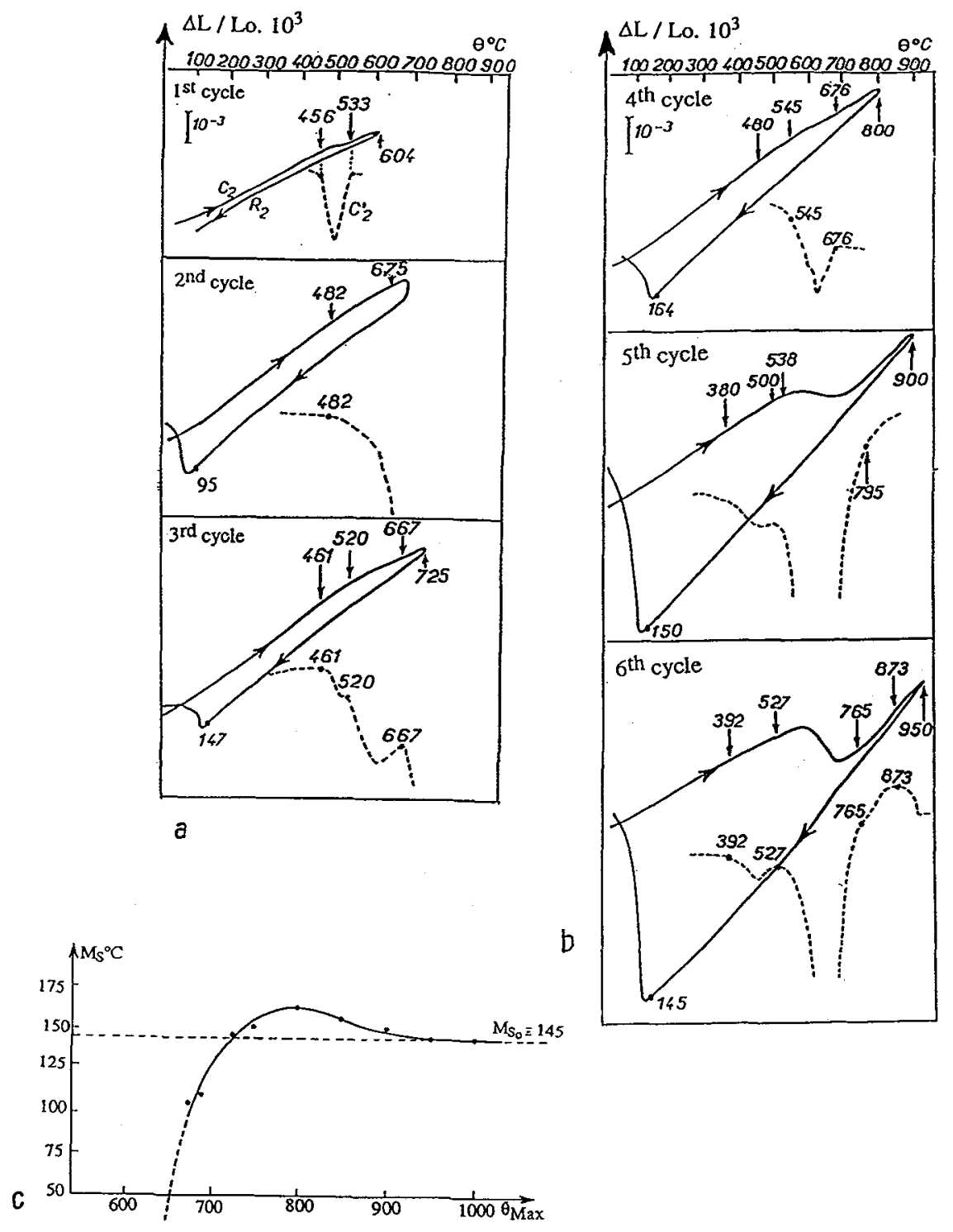

Figure $4:-$ ( $\mathrm{a}$ and $\mathrm{b}$ ) dilatometric curves of $\mathrm{PH}$ 15-5 alloy recorded up to various temperatures between 600 and $950^{\circ} \mathrm{C}\left(R_{h}=R_{c}=300^{\circ} \mathrm{C} \cdot h^{-1}\right)$, -- derivative curves.

(c) Ms values as a function of the maximal temperature reached $\theta_{\mathrm{Max}}$.

These results can be interpreted by a progressive impoverishment in alloying elements of the retained austenite $\left(\gamma_{r r}\right)$, in particular in copper and in nickel up to the point where the nominal composition Co is found again. 
In the range $600<\theta_{\mathrm{Max}}<700^{\circ} \mathrm{C}$, other processes are superimposed on the formation of the retained austenite :

- on the one hand, the ripening of the first type of precipitates formed takes place before the point $\mathrm{A}_{c d}$ (called (B)) Figure 3b.

- on the other hand, the formation of a second type of precipitates (called (C)) with f.c.c. symmetry, is observed [5], as is shown in Figure 3c. The dissolution of precipitates $\mathrm{B}$ between 650 and $690^{\circ} \mathrm{C}$ also takes place.

In the $\theta_{\text {Max }}$ range between 725 and $800^{\circ} \mathrm{C}$, two processes proceed simultaneously :

- the impoverished martensite (Mrp is transformed into a more and more impoverished austenite according to the reaction: $\quad \mathrm{M}_{\mathrm{rp}} \rightarrow \mathrm{M}_{\mathrm{rpp}}+\gamma_{\mathrm{rpr}}$.

$\mathrm{M}_{\mathrm{rpp}}$ of concentration Crpp<Crp (the concentration of Mrp).

$\gamma_{\mathrm{rpr}}$ : austenite more and more impoverished.

During the final cooling process this leads to Ms values higher then $\mathbf{M s}_{\mathbf{O}}$.

- the coalescence of the precipitates $(C) \rightarrow$ precipitates $(D)$, Figure $3 \mathrm{~d}$.

At temperatures above $800^{\circ} \mathrm{C}$ the precipitates (D) dissolve in the austenite matrix $\gamma_{\text {rpr }}$, which enriches this phase slightly in copper and in nickel. Consequently, during the final cooling process, the transformation values $\mathrm{Ms}$ approach progressively $\mathrm{Ms}_{\mathrm{o}}$, Figure $4 \mathrm{c}$.

Between 930 and $1015^{\circ} \mathrm{C}$, Figure 2, the second step of the austenite transformation takes place according to the reaction $\mathrm{M}_{\mathrm{p}} \rightarrow \gamma_{\mathrm{p}}$ (probably a diffusion process of type $\mathrm{M}_{\mathrm{p}} \rightarrow \mathrm{M}_{\mathrm{pr}}+\gamma_{\mathrm{pr}}$ ).

\section{CONCLUSION}

The results obtained by dilatometric study of the transformation mechanisms in the alloy PH 15-5 are summarized as follows.

The transformation $\mathrm{M} \rightarrow \gamma$ proceeds in two successive steps, for a moderate heating rate $\left(300^{\circ} \mathrm{C.h}-1\right)$ : -the first step is controlled by diffusion processes whereas the second one is related to the transformation as follows : impoverished martensite $(M p) \rightarrow$ impoverished austenite $(\gamma)$.

-the temperatures of the transformation points $A_{c d}$ et $M s$ respectively vary with the maximal temperature reached during the heating process (in particular in the intercritical domain).

The martensitic transformation $\gamma \rightarrow M$ is a one step process accompanied by an expansion. The expansion amplitude is considerable if the alloy is homogenized at a temperature above $\mathrm{A}_{\mathrm{cfo}_{\mathrm{o}}}\left(1015^{\circ} \mathrm{C}\right)$.

\section{ACKNOWLEDGMENTS}

The author is indebted to Professor G. Cizeron for providing the facility for dilatometric experiments and for fruitful discussions. I am very thankful to Dr.C. Servant for a stimulating collaboration during the course of this study. I would like to acknowledge Messrs P. Arevalo and M. Lucas for the dilatometric sample preparation.

\section{REFERENCES}

[1] W.A. Peterson, Welding J. 43, 428 (1964).

[2] C. SERVANT, Thèse de Doctorat-ès-Sciences Physiques Université de Paris-Sud (1972).

[3] N. BOUZID, Thèse de Doctorat en Science Université de Paris Sud (1987).

[4] H.R.HABIBI BAJGUIRANI, R.MOLINS, C.SERVANT, J.L.STRUDEL, G. CIZERON, (1993) to be published.

[5] H.R.HABIBI BAJGUIRANI, C.SERVANT, G.CIZERON. Acta Metall. Mater, vol.41, No.5, pp.1613-1623, (1993).

[6] N. BOUZID, C. SERVANT and G. CIZERON. Acta Metall, Vol 36, No. 6, pp. 1527-1536, (1988). 